\title{
Linear and Nonlinear Strategic Management: With Applications to Shipping
}

\author{
Alexandros M. Goulielmos ${ }^{1,2}$ \\ ${ }^{1}$ Marine Division, Business College of Athens, Athens, Greece \\ ${ }^{2}$ Department of Maritime Studies, Marine Economics University of Piraeus, Piraeus, Greece \\ Email: agoulielmos@bca.edu,grag@unipi.gram,goulielmos@hotmail.com
}

How to cite this paper: Goulielmos, A.M (2018) Linear and Nonlinear Strategic Management: With Applications to Shipping. Modern Economy, 9, 97-124.

https://doi.org/10.4236/me.2018.91007

Received: November 9, 2017

Accepted: January 9, 2018

Published: January 12, 2018

Copyright (c) 2018 by author and Scientific Research Publishing Inc. This work is licensed under the Creative Commons Attribution International License (CC BY 4.0).

http://creativecommons.org/licenses/by/4.0/

\begin{abstract}
The strategies-corporate, competitive and current-and the "effective leadership", provided by linear management-all in all 22-were briefly presented with an application to shipping industry, like BCG matrix, and growth, as well as how to create and maintain a competitive advantage. Moreover, the essential strategies/functions of a shipping company were too presented with the prime emphasis to timing of shipping decisions. In shipping, management, as showed, is done by distance. Nonlinear management strategies showed next and the full Cartesian diagrams-phase spaces-of 3 companiesone in shipping-were used to discover the level of chaos in their business activities. A further tool has been used from nonlinear management: the "span of management" vis-à-vis the well-known "span of control". We have showed that both top maritime countries and top shipping companies pursue the "growth strategy in a related industry" (with same knowhow). Some countries did it better, like Greece and Germany. "Growth strategy" has been accompanied by economies of scale and a lower service cost. We showed also that a growth strategy has to be moderated by: 1) forecasting that demand will be there, when ships are delivered; 2) that liquidity is secured, even in a slump, where banks and stock exchanges turn their backs to shipping, 3) the fact that prices of ships-new or $2^{\text {nd }}$ hand-were indeed at rock bottom and that the $1^{\text {st }}$-best or $2^{\text {nd }}$ best timing has been applied and 4) that company's investments did not influence total supply so that to dampen markets. A mention on generic competitive strategies has been carried out and especially differentiation issue of products and services, but not pursued much as shipping has homogeneous services.
\end{abstract}

\section{Keywords}

Linear and Nonlinear Management, Strategies, Mission, Growth Shipping Strategy, Full Cartesian Diagram, Span of Management and Control, The 
Strategies of a Shipping Company, Timing, Companies Case-Studies

\section{Introduction}

This paper provides several presentations: one is the concise analysis of what we have called "linear strategic management", which is the mainstream management strategic theory. For this we have used the most up dated source in USA, including current strategies. We have been surprised for the extensive list of strategies that theory provides, where we have counted 22 various strategies... From this list we have singled out the ones that have been used by shipping companies like: growth strategies including economies of scale and cost leadership.

The $2^{\text {nd }}$ presentation concerns the essential roles and strategies that a shipping manager has to perform, where timing of the decision-making holds the prime place. The $3^{\text {rd }}$ presentation deals with the important concept of linear management like mission. The $4^{\text {th }}$ presentation deals with nonlinear management strategies, which cover a more extensive analysis as we have presumed that the reader may be unaware of it.

Worth noting is that: the definition of "strategic management" is tautological, as it says that strategic management is "what managers do to develop organizations' strategies"... applying a strategy does not also mean "making money", and the 1970 "strategic planning model"-invented by "General Electric Co"-a 7-step process-is static.

This last model gave $43 \%$ attention to company's mission and to the application of SWOT analysis. It gave also attention to present, which no one can change. SWOT - as it is known-is a composite concept meaning company's external analysis for: threats, opportunities and internal analysis for: strengths and weaknesses. The other $57 \%$ of the model was: 1 ) to recognize 3 strategic issues (growth, risk, competition), 2) to identify strategic alternatives and 3) to decide upon them. There was no evaluation of strategies' step.

Modern authors removed 2 of the original steps of SPM and added a $6^{\text {th }}$ step (= "evaluation of the results of company's strategies"). Evaluation was necessary no doubt. Two steps removed-wrongly: the "identification of alternatives" and "the decision-making of them".

\section{Aims and Organization of Paper}

One aim is to introduce the tools of nonlinear management by showing its usefulness vis-à-vis linear management. This is done with a number of graphical applications (using the full "Cartesian" diagram) to 1 shipping company and 2 shore companies. Second aim is to present briefly the existing fourteen linear strategies, and review them. Emphasis all along is given to those strategies applied by, or applicable to, shipping companies like growth strategies, economies of scale, and timing of decisions. 
The paper is organized as follows: next is a literature review, followed by a brief presentation of the (14) existing linear strategies. Then, the main functions performed by a shipping company are presented by order of importance. Next, a presentation of the linear management central concept of "mission" is done. This is followed by a presentation of the nonlinear management strategies. In addition 3 case-studies of companies are shown in their "phase spaces"1-including the case-study of a major shipping company in the transportation of "oil-products". Finally, we conclude.

\section{Literature Review}

Research on "shipping management" is rare, and of a rather late appearance, despite its great importance. The pioneers in this endeavor belong to 4 schools:

$\checkmark$ The Norwegian school (1973) represented by: Lorange and Norman (editors) 1973 [1]; Norman, 1982 [2]; Lorange, 2005 [3]; 2007 [4]; 2008 [5]; 2009 [6]; 2010 [7]; Lorange and Fjeldstad, 2010 [8], 2012 [9].

$\checkmark$ The American school (1973), represented by: Kendall l C (1912-1999); Buckley ${ }^{2}, 2008$ [10]; Marton G S; and Huber ${ }^{3}, 2010$ [11].

$\checkmark$ The English school (1981) represented by Packard ${ }^{4}, 1981$ [12]; Downard ${ }^{5}$, 1981 [13], 1984 [14]. The English school started by publishing a series of books—called "ship management"-designed to provide a helpful advice on the more practical aspects of ship operations and management.

$\checkmark$ The Greek school (1992) represented by Dr. Goulielmos, (2004 [15]), (Goulielmos, 2002 [16]; 2017 [17]), and by Dr. John Theotokas of Aegean University (2007 [18] with Mrs. Harlaftis).

The lack of shipping management studies are due-we believe-to the fact that most maritime authors in Academe ignore shipping management and those in shipping management do not become academics-with few exceptions. There is also the secrecy of the actions of shipping industry, excluding "listed shipping companies" and/or "those that provide management" to other shipowners for a fee. Listed shipping companies are transparent and as a result Academe is informed indirectly about their actions and strategies.

\footnotetext{
${ }^{1}$ Graph allowing all possible states of a system. The points in a phase space are attracted by a cycle, i.e. the "limit cycle" attractor.

${ }^{2}$ Mr. Buckley is a BS graduate of California Maritime Academy (1971), with a master's license (19761984) on tramp and liner vessels; he obtained a master's degree in business administration and joined the faculty of the above academy (1985); currently is a professor in the dept. of marine transportation; he obtained a doctoral degree in organizations and management.

${ }^{3} \mathrm{Mr}$. Huber is a graduate of the State University of New York Maritime College; he obtained a master's degree in environmental studies from Long Island University; ex Captain; currently is a Professor in the dept. of marine transportation at the same dept. (US merchant marine academy (NY)).

${ }^{4} \mathrm{Mr}$. Packard born in London made his career in shipping and in the operations of most types of vessels including bulk carriers and chemical tankers; employed by a member company of "Baltic Exchange".

${ }^{5} \mathrm{Mr}$. Downard (1928-) joined P \& O Group (1944), signed on tramp ships and bulk carriers; signed off and appointed in various managerial shipping posts (1968); he was managing director of a London ship management company (1975); similarly he held various posts as a director in shipping companies.
} 
Interesting is Mr. Peter Lorange, who is Professor of International Shipping at IMD (Lausanne) and former owner of a Norwegian shipping company (2007). Lorange (2009 [6], no number of page) argued that traditional shipping companies-meaning those having shipping under one organizational roof-are on decline. The new generation of shipping companies-for Lorange [6] p.xiv]pursues specialization with strategic clarity and managerial focus; also innovation. Lorange (2009 [6] p. xiv) further argued that specialization should be round 1, or 2 at most, of the existing 4 archetypes: 1) owning ships, 2) chartering ships, 3) trading in the markets/perform properly ship operations, and 4) make innovations related to the technical as well commercial aspects of shipping.

Lorange (2009 [6] p. xiv) claimed that specialization is the future trend-and by this, a shipping manager would achieve less complexity, less coordination, less bureaucracy, more strategic clarity, and increased managerial focus. Moreover, an overall portfolio strategy is needed and management of overall risk $^{6}$ ([6] p. $\mathrm{xv}$ ). This policy, we reckon, corresponds to "putting all eggs in one basket".

Important portion of this paper deals with the application of Chaos Theory to

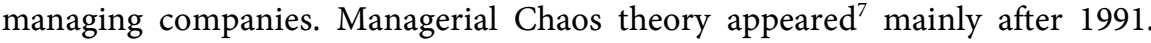
Phelan $(1995,[19])$ argued that Chaos theory provided the capability to deepen substantially in the nature of the complex systems in business. He argued that the increased turbulences in business and the global speeding up of the occurrences of changes, introduced chaotic elements into businesses.

Levy $(1954,[20])$ wrote that chaos tends to be seen in almost all managerial systems, and he was the one to use-as a pioneer-a nonlinear simulation of the chain of international supplies, where managers underestimated their cost. This would result to an unstable and stop-go production function and managers had to control the production process so that to relocate it in a stable situation. Stacey (1991, [21] and 1993 [22]) argued that the models we observe... all show the importance of chaos in management practice. Vinten (1992, [23]) saw the theory of chaos as the next important penetration of it into management.

Kellert (1993, [24]) defined the theory of chaos as the qualitative study of unstable non-periodic behaviors of deterministic nonlinear dynamic systems. A system here is determined from its most important variables and from its interrelationships with a set of equations. The system is dynamic if the equations are able to describe changes in the values of the variables from a point of time to other. Goulielmos (2015 [25]) provided a full analysis of how complexity and chaos theories reformed management and Goulielmos (2002 [16]) showed how complexity theory has been applied to management of shipping companies.

In summary, we see that research on shipping strategic management has been

${ }^{6}$ The effort to face risk is bound to fail, as its current definition corresponds to standard deviation- $\sigma$, which almost excludes by probability-outliers, i.e. outcomes beyond $3 \sigma$. The measures of risk today are: "alpha"- $\alpha$ (volatility) and "beta"- $\beta$. Alpha gives the peak of a distribution, and the amount of fat, which is accumulated in its tails, where most surprises are to be "discovered". In 1987 black Monday the Dow went away from mean $22 \sigma \ldots$ A stock now with a beta equal to 1 moves in lockstep with the market overall. Beta is central in building out companies' portfolios in linear finance.

${ }^{7}$ The chaotic management and organization of companies counted 2 publications by 1991. 
poor and of a late appearance and as well from a limited number of authors, so it is not surprising to see almost a non-existing research also on nonlinear shipping strategic management.

\section{The Linear Management Strategies}

According to linear management studies-LM a manager has to "identify company's mission, goals ${ }^{8}$ and strategies"'; then carry-out external and internal analyses; the $4^{\text {th }}$ step is to formulate 3 composite strategies of... 14 particular strategies, i.e. the corporate, competitive and current. The $5^{\text {th }}$ step is to implement the strategy (-ies) chosen, and the $6^{\text {th }}$ step is to evaluate ${ }^{10}$ their relevant results.

LM theory argues that "strategic management" helps for a good "performance", and that there is a positive relationship between "strategic planning" and "performance". Our personal opinion is that a flexible (Figure 7) strategy is needed nowadays as companies' situations are changing fast, and companies became complex. This we reckon is a result of the advances in computers, in information, in communications and by confronting meltdowns. Additionally, there is the "effective"11 strategic leadership, which appeared in 1999, with 8 components (Robbins and Coulter, [26]: p. 249).

$\checkmark$ The corporate strategies consist of 4 particular strategies (Figure 1).

Interesting is BCG for shipping, which could classify company's ships in 4 categories... and sell first the "ships-dogs", and eventually the "ships-cash cows"... and perhaps increase-by buying or building-the "ships-stars" and "ships-question marks"... The ships-cash cows must be kept till a slump is over for liquidity purposes.

$\checkmark$ The dominant strategy: growth

This is to "maximize the size of the company". This strategy means-for shipping companies-"maximization of the fleet-owned", or more accurately the "amount of dead weight tons ${ }^{12}$-owned"13. Below (Figure 8) we show what impact has " $1^{\text {st }}$-best" timing on this.

This "growth strategy" is shown among the global top 10 maritime nations (Figure 2 and Figure 3).

As shown, 10 leading shipping countries globally spent $~ € 176 \mathrm{~b}$ ( $67 \%$ of total) in 2007 (a boom year) to order 3371 ships ( 63\% of total). Germany is first in

\footnotetext{
${ }^{8}$ What company's goals have to do here?

"A process for "strategic management": should it include "strategies"?

${ }^{10}$ Xerox e.g. after evaluation of company's strategies, "cut jobs, sold assets and reorganized management"...

${ }^{11}$ The 8 targets/strategies are: 1) determine company's mission or vision; 2) exploit and maintain core competencies; 3) develop human capital; 4) create and sustain a strong culture and 5) company's relationships; 6) reframe prevailing views; 7) emphasize ethical decisions and 8) practice and establish properly balanced controls.

${ }^{12}$ The carrying capacity of a ship is denoted by her deadweight tons. This is the "weight of cargo", at $95 \%$, that she can carry reaching her load lines (on top of bunkers, water etc.).

${ }^{13}$ The number of ships owned is misleading in giving us an idea of the size of a shipping company. e.g. a company owning 3 vessels is considered average, but if it owns 3 vessels of 500,000 dwt is considered very large.
} 


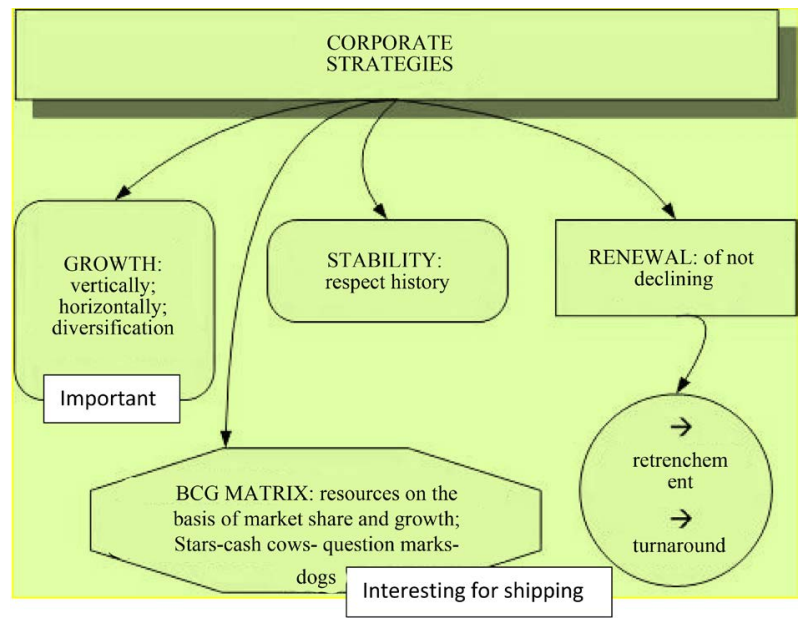

Figure 1. Corporate strategies. source. inspired by robbins and coulter, [26], p. 241-3.

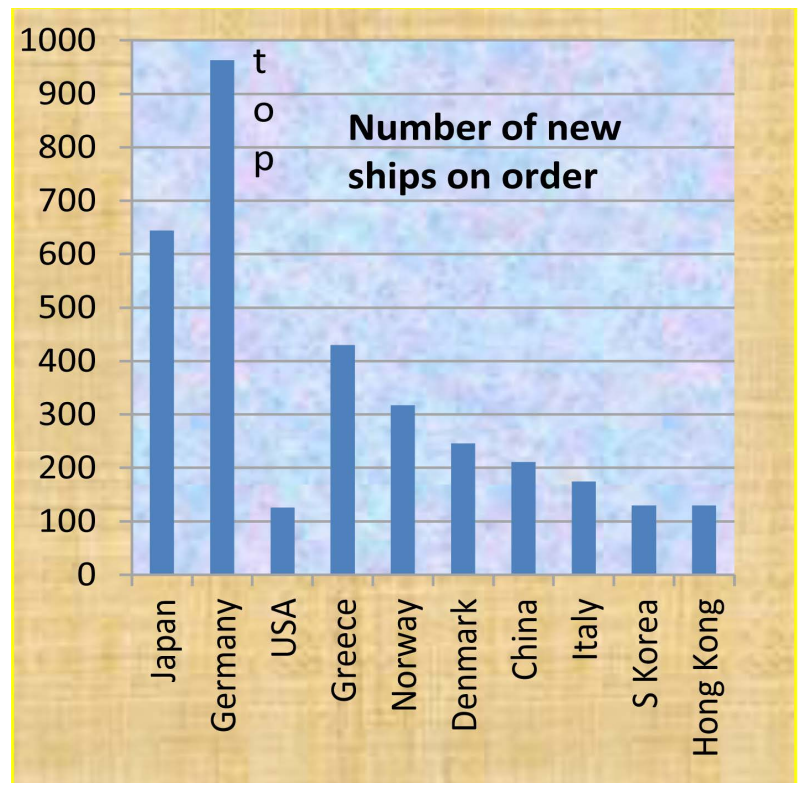

Figure 2. 10 top countries 2007 (No of ships on order). Source. Data from Lorange (2009 [6], p. 122).

number of ships ordered with 963 units (29\% among top 10); Japan-a leading shipbuilding country-is leader in the funds spent of $\sim € 37 \mathrm{~b}$ or $21 \%$ among top 10.

Interesting is to see economies of scale (Table 1) by calculating average prices, as: the more expensive is a ship, the larger could be. USA has ordered 126 units, which are the most expensive, spending $€ 21.5 \mathrm{~b}$ (12.2\% among top 10).

As shown, Greece and Germany achieved the lower prices, fact which will make them more competitive in future. The new ships-we reckon-are larger than hitherto, and this indicates not only a growth strategy, but also economies of scale. Economies of scale-as this is known-provide cost advantage (given demand). 


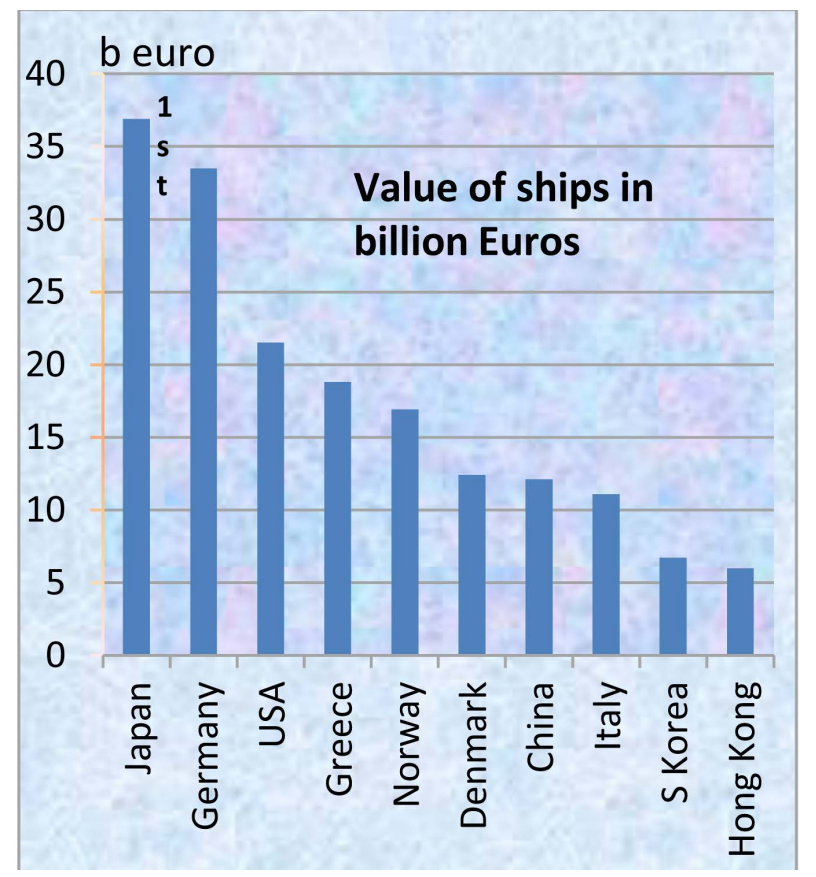

Figure 3. Funds spent for new ships-2007-by 10 top maritime countries (billion $€$ ).

Table 1. Average value of ships ordered in 2007 by 10 top maritime countries.

\begin{tabular}{ccc}
\hline Position & Country of control & Average price (Million $€$ ) \\
\hline 1. & USA & 171.0 \\
2. & Italy & 63.8 \\
$3 \& 4$. & Japan $\left(^{*}\right)$-China $\left(^{*}\right)$ & 57.3 \\
5. & Norway & 53.3 \\
6. & S Korea $\left({ }^{*}\right)$ & 51.5 \\
7. & Denmark & 50.4 \\
8. & Hong Kong & 46.1 \\
9. & Greece & 44.0 \\
10. & Germany & 34.8 \\
Other Nations & & 43.8 \\
\hline
\end{tabular}

Source. Figure 2 \& Figure $\left.3 ;\left(^{*}\right){ }^{* *}\right)$ Top shipbuilding countries.

Next, we present the fleets of 10 top Greek shipping companies in 1990 and in 2000, having exceptional (double) rates of growth in tonnage. This is shown by the different amounts marked on vertical axes of Figure 4 and Figure 5. Figure 4 shows the fleets, which reached $2.75 \mathrm{~m}$ GRT maximum, while in Figure 5, they reached $4.75 \mathrm{~m}$ GRT maximum.

The growth strategy we saw above means additions of identical operations with a view to gain advantages from additional economies of scale, where know how is unchanged or improved by learning (best example: Greek shipping). 


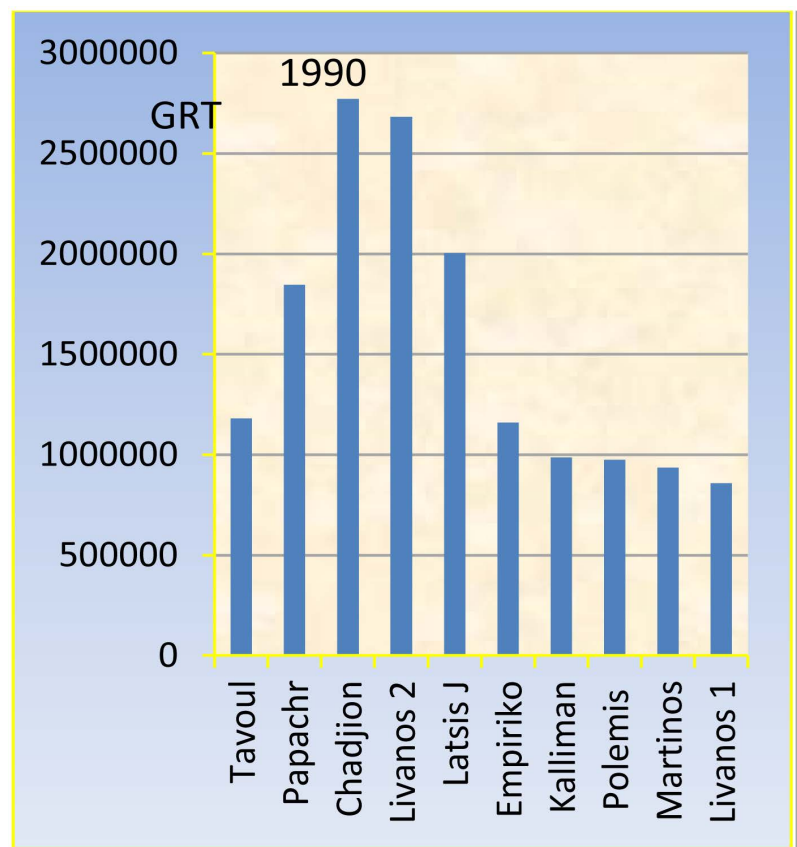

Figure 4. 10 top Greek shipping companies in 1990 (million GRT); Source. Data from various shipping monthly magazines (various years) and mainly from "Naftiliaki" monthly journal. GRT = gross registered tons (another measure of carrying capacity in volume).

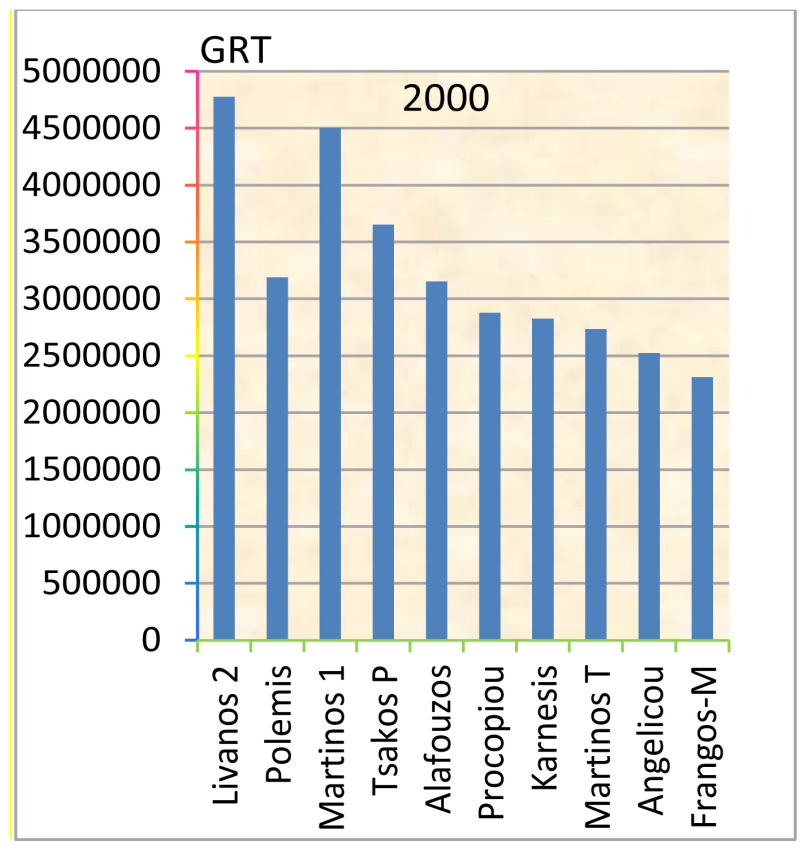

Figure 5. 10 top Greek shipping companies in 2000 (million GRT).

There are also many examples for growth in related industries (called circular), 2 of which can be ${ }^{14}$ found in Lorange (2009, [6] p. 83). In shipping, many shipping

${ }^{14} \mathrm{~A}$ "dredging" firm (= "van Oord") "transplanted" its dredging of harbors to building artificial islands (in Dubai etc.). Moreover Skaugen I M did a joint venture with "Teekay" to provide freight "barging" on major rivers and moreover to transport LPG and other chemicals (in China and elsewhere). 
firms have expanded into shipbuilding (e.g. Niarchos; A.P. Moller-Maersk, and many others), causing changes in company's "structural characteristics". This growth can provide a number of advantages like building (repairing) ships cheaper, and in time, and embody innovations. However to attract customers/ships-except founder's ships-is difficult as this would mean to make a competitor stronger...

In shipping we have also seen many cases of mergers (e.g. "OMI shipping Co" bought by "Teekay"), i.e. effort of one listed company to buy-out competitors. Growth in unrelated industries positions a company in 2 independent markets, but there is a risk due to diversification. Shipping is a cyclical industry and an investment that provides profits during a shipping slump is desirable. Most shipping companies resort to investments in real property considered them of a stable rising value. Moreover, shipping companies diversified their fleet by entering in ships, sizes and markets unknown to company before (e.g. product carriers; VLCCs \& ULCCs; LNGs; LPGs; car carriers; gas carriers; vale carriers etc.).

\section{$\checkmark$ Competitive strategies}

"Competitive strategies" is another composite concept, including 4 particular strategies (Figure 6).

A shipping company does not set off in "strategic business units", but many times sons and daughters-after the death of their father-shipowner-set off new companies (Goulielmos, 2017 [27]). The self-understood "functional strategy" concerns all company's departments-and ships' captains for a shipping company-to support ${ }^{15}$ company's "competitive strategy".

Most important is the strategy to create and sustain company's competitive advantage(s), using 3 particular methods/tools: (1) quality, since 1991, (safety for

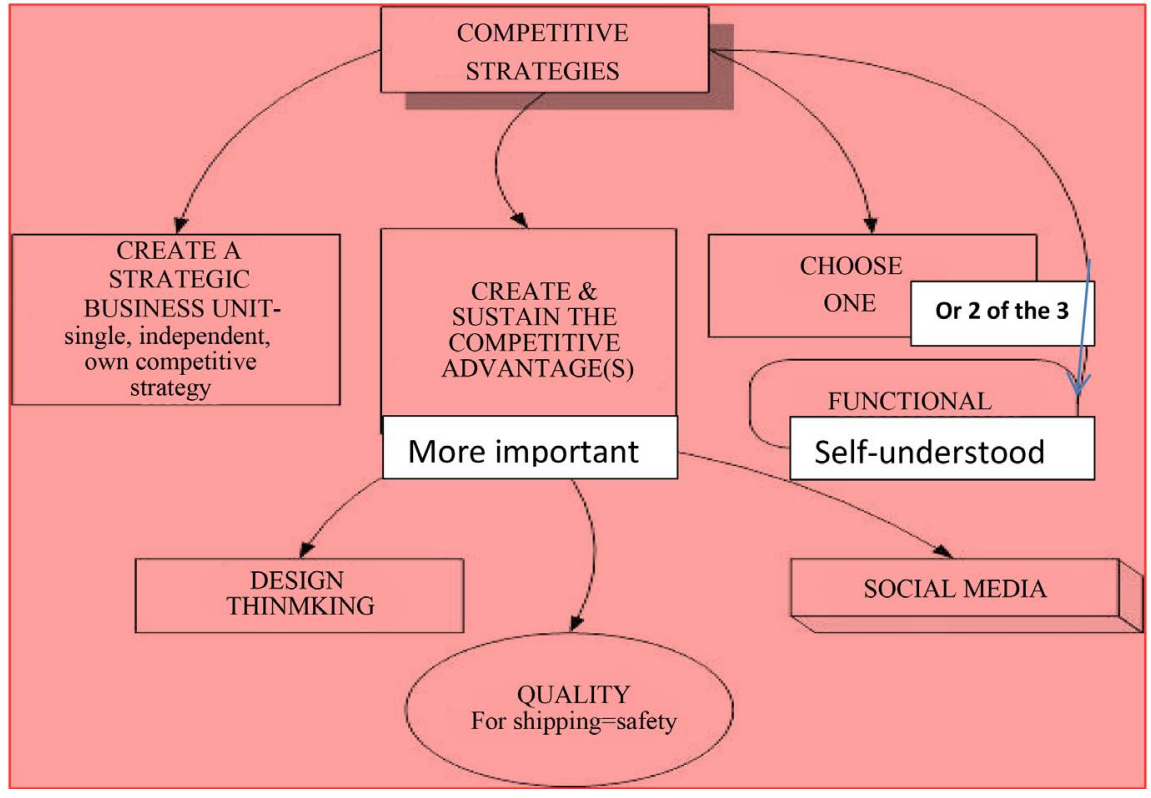

Figure 6. Competitive strategies. Source. Inspired by Robbins and Coulter, [26], p. 241-3.

\footnotetext{
${ }^{15}$ This is par excellence true during a slump.
} 
shipping since 1998); (2) social media (a contemporary tool) and (3) design thinking (a modern approach since circa 2006).

Design thinking means-for shipping - to have charterers to be able to find anything they want on line; or it means-in general-approaching management problems $^{16}$ the same way one solves design problems (e.g. "Kiva systems", a Chinese company). USA shipping company OMI (bought by Teekay) had the chartering of its ships on line. Social media can be useful for the communication of large company's staff (say 250 - 300 persons) of shore office with ships' crew amounting to 1500 for large companies. In addition, "big data" may appear a strategic weapon for shipping acting internationally, as all big global events influence shipping.

"Quality" of products creates a competitive advantage, but in shipping we need "quality of services". "Quality of shipping services" is confused with "safety". "Total safety management" is in shipping required for a shipping company to be considered "standard", but this does not influence the level of the payments of freights; lack of safety is illegal ${ }^{17}$, however, and charterers demand it... A shipping manager will not permit charterers to consider his/her company of having "sub-standard" ships — though safety means cost. Some shipping companies try to differentiate their services-or rather show off-by obtaining ISO standard for management and/or for environment.

Theory considers the creation of a competitive advantage difficult, but to sustain it-we reckon-is more difficult... Certain shipping companies may excel in caring to satisfy their charterers, providing safety on board (and security in ports complying to ISPS ${ }^{18}$ code-2004), having a minimum of loading/unloading interruptions (black-outs), being polite and willing to respond to the demands of the charterer that do not cost anything to owner etc.

$\checkmark$ Secure cargoes: a unique shipping strategy

A superior shipping strategy followed by shipping entrepreneurs, was and is, to secure-somehow or anyway-cargoes, perhaps by creating best personal public relations with cargo-owners. Best example of international public relations was Onassis in his unsuccessful effort to secure part of the Saudi Arabian oil transport, using a win-win strategy.

Another example is "Gearbulk" in Brazilian pulp business concerning the companies "Aracruz", "Suzano" and "Votarantine" (Lorange, 2009, [6], p. 108, 106-7]). Gearbulk became market leader in shipping cellulose from S American producers by investing in expensive gantry cranes on board. Another example was late Mr. Manios M, who secured part of the oil transport of Mexico by creating personal relations with the highest persons in Government. In the distant past, there was no problem in finding cargoes as a shipowner was also a

${ }^{16} \mathrm{D}$ Dunne \& R Martin, (2006), Design thinking and how it will change management education, interview and discussion, Academy of management learning \& education, Dec., pp. 512-523, cited in Robbins and Coulter [26], p. 607.

${ }^{17}$ Shipping is the only industry to have a "police" for law enforcement. This police is the "Port State Control" and the law is mainly SOLAS convention 1974 (as modified).

${ }^{18}$ The "International code for the security of ports and ships": a product of the $11^{\text {th }}$ Sept. 2001. 
merchant... Subsequent specialization solved some problems by creating some others...

$\checkmark$ Current strategies (6 strategies) (Figure 7).

As shown, strategic leadership - but not effective-is a composite task, or a shopping list, requiring: ability to anticipate, envision, maintain flexibility, think strategically, and work with others-in house-to create a viable and valuable future...In strategic flexibility, we have to recognize the major external changes, to commit fast required resources and recognize a wrong strategy ${ }^{19}$. The $1^{\text {st }}$ mover has 4 advantages and equal disadvantages, and applied also to shipping. As shown, 3 current strategies are more important: e-business, innovation and be close to customers.

\section{The Essential Functions of a Shipping Manager}

All shipping companies have to carry-out, and plan yearly, key-tasks, which are next presented by order of importance. Worth noting is that a shipping company is a "multi-plant" firm, where its factories = ships, are floating, and move internationally, and more important is that management is done by distance, as the manager is in the shore office-say in Piraeus-and the ship miles away-say in Arabian Gulf.

Cheap and fast communications are thus vital for the shipping industry. This means obligatory delegation to Captains. This further means the need of an increasing control (by distance). This also means increased formalization (rules and procedures), and the inability to control in advance. Errors can only be punished! This further means the importance of the selection procedure of Captains as co-managers, and not as crew.

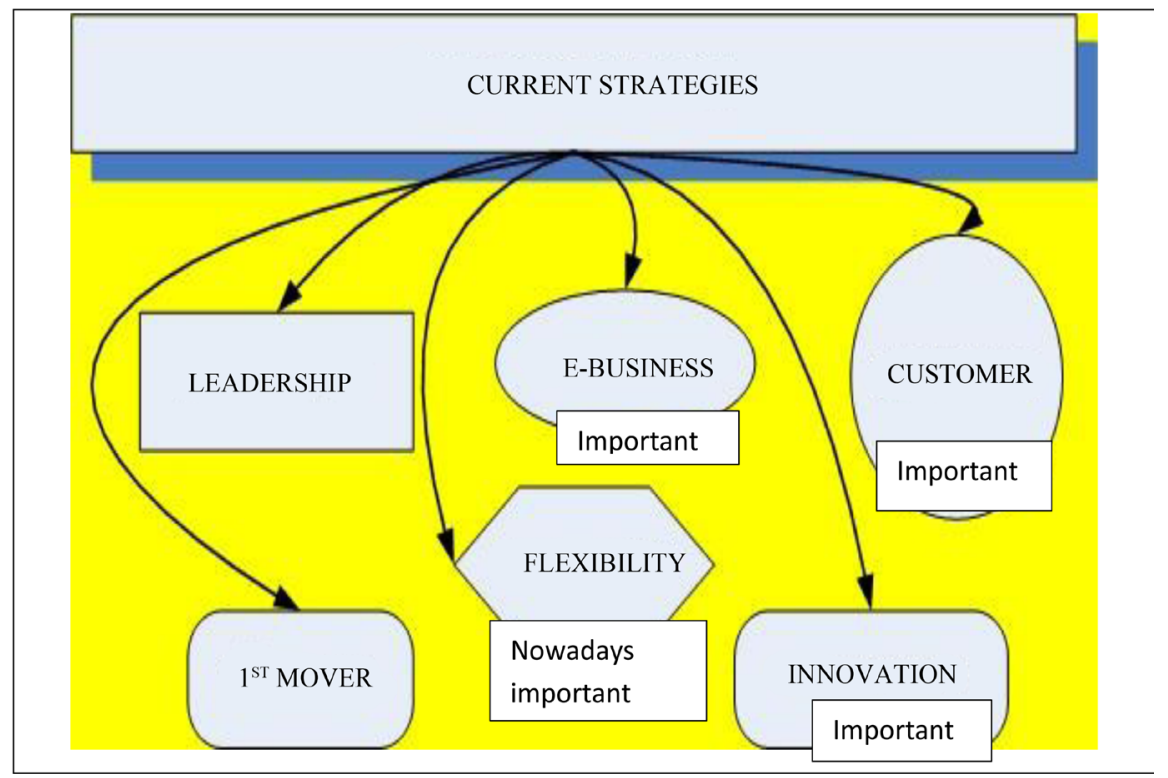

Figure 7. Current strategies. Source. inspired by Robbins and Coulter [26], p. 247.

\footnotetext{
19“"Hapag-Lloyd" sold-off its terminals; this was considered as a strategic mistake (Lorange [6] p. 210).
} 


\section{$1^{\text {st }}$-best timing}

This is the most important shipping managerial strategy: i.e. the proper "timing of shipping decisions" (Lorange [6] p. 135, and everywhere in his book). The manager who respects " 1 st -best timing" is the "King" in shipping, as shown (indirectly) by Figure 8.

As shown, the cyclicality of new building prices over the last 29 years is clear, and the period of "shipbuilding cycle" according to theory (Pearce, 1992 [28]) is equal to BCDEF $(1982-1996=\sim 14$ years) or EFGHI $(1992-2007=\sim 15$ years), with an amplitude of $\sim \$ 35$ million. Moreover, the $1^{\text {st }}$-best timing to order ships is 1985 (= price $\sim \$ 90 \mathrm{~m}$ ) and the $2^{\text {nd }}$-best is between 1989 and 2002 (= price $\sim \$ 110 \mathrm{~m}$ ); bad timing is 2007-2008, where price was near $\$ 190 \mathrm{~m}$.

Shipping managers, with the ambition to grow their companies-following a fast growth strategy-usually, rush to premature orders and acquisitions of ships. Then, they realize a few years after that the same ships to be valued at $1 / 3$ of what they have paid!

As all shipping variables change rapidly, the $1^{\text {st }}$-best timing concerns shipping decisions starting from this question: "Is this the right time-of all past times -for us to...?” The $1^{\text {st }}$-best timing, however, has its own speed and is this speed managers should have, if they want to apply timing. Crucial here is how the company has organized its information flow, as the shipping international reality changes from a minute to next. Ships, anyway, work 24 hours...

Fundamental for shipping companies is also to know if they act in markets "permitting" price-taking, where the tools of marketing are of limited help (Goulielmos and Plomaritou, 2009 [29]). If a company is a price-taker this makes a great difference in adopting the proper strategy. Increasing for example the advertising budget, to achieve more sales, has no point. This in turn means that in order to judge the performance of a company's management, one has to

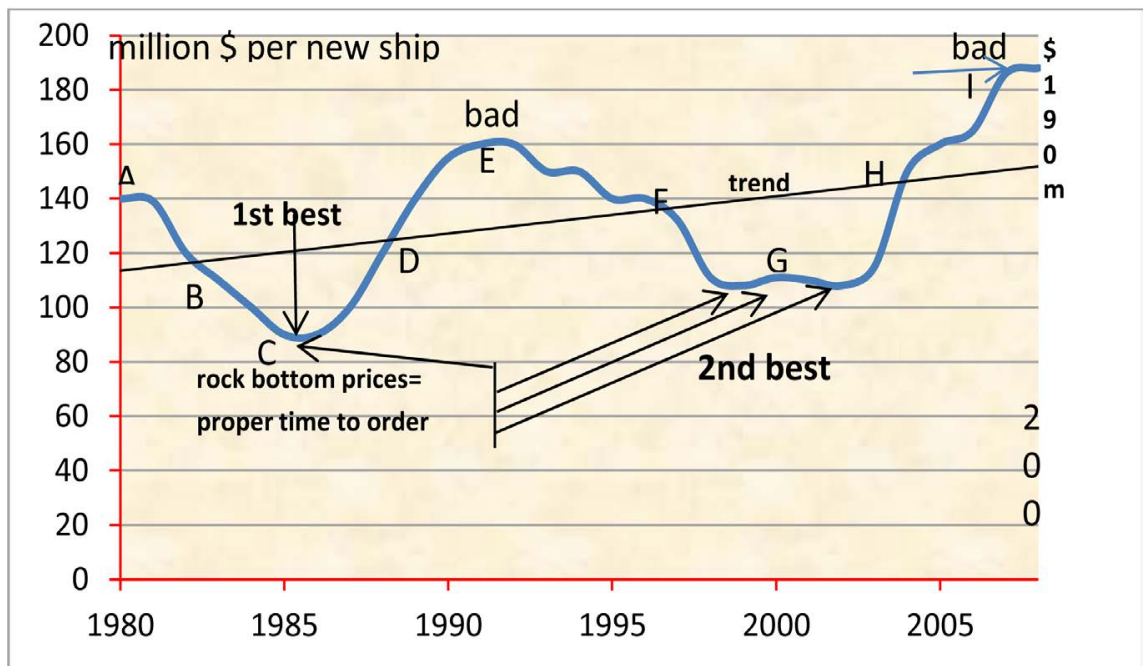

Figure 8. Newbuilding prices, 1980-2008. Source. Data from Lorange (2009, p. 126, [6]). Slump(s) in dry cargo freight markets started in $1981-2^{\text {nd }}$ half till $1987-1^{\text {st }}$ half and in 1991+; the boom started in 2003 till 2008. 
take into account similar or identical market conditions, as well as other essential factors.

An individual manager should thus control company's cost. "Cost minimization" is the 2 nd proper, and permanent, we would say, strategy, after " ${ }^{\text {st }}$-best timing", and especially during slumps. As shown (Figure 8) indirectly, the prime strategy is the minimization of "capital cost", through $1^{\text {st }}$-best timing, as this cost covers $1 / 2$ of (new ship's) total cost. Moreover, this, called also "cost leadership" (Besanko et al., op. cit., [30], p. 308) provides to non-shipping companies a competitive advantage. In shipping this strategy provides "survival", or an "increased profitability", as profit (fixed) = total revenue (fixed) minus total cost (variable).

The fixed price dictates also to a manager what is known as "in-and-out" policy (Lorange, 2009, p. 42, [6]). This means that a shipping manager is not $o b$ liged to stay in a bad market, and accumulate losses, but he/she can get out by shutting-out his/her uneconomic ships. This is known as laying-ships-up. The company has to be prepared for such a policy as a crisis is expected every 10 years on average, but no shipping manager knows yet when...

$\checkmark$ To understand economics

A manager has to deal primarily with company's loans, and to design how to "manage": company's financial flows ${ }^{20}$, the budget, the currencies, the interest rates, and the new instruments and derivatives (related to FFAs = forward freight agreements). It is estimated (Lorange, 2009 [10], p. xii) that the volume of FFA trading for dry bulk shipping-and for tankers, but not yet for containerships-for one year (2007-2008) is equal to physical trading...Interesting is to know also the amounts lost by shipping companies in this trading (e.g. "Teekay" lost $\sim \$ 96 \mathrm{~m}$ ). Hedge funds and financial brokers showed an increasing interest in shipping derivatives during recent boom (2003-2008).

The knowledge of economics of various markets (bulk, tanker, containerships etc.), and of their sub-markets, is essential, as shipping markets have different characteristics. Certain shipping companies hire economists for this, especially those with prior good banking public relations. Most shipping companies "keep" this function wrongly for company's management for reasons of confidentiality. Shipping managers most of the cases lack knowledge of economics, and finance, excluding current generation, which studies "money and finance" in various masters' degrees. When markets turn, is crucial this to be spotted beforehand by the able manager, but accurate forecasting is the weak point of this industry (Goulielmos, 2017 [31] forthcoming).

A factor, which bankrupted shipping companies many times, is the lack of $l i$ quidity, especially during a slump. To the same effect works also a prior ambitious newbuilding program coincided with a subsequent fall in rates upon ships' delivery. After a slump, banks ${ }^{21}$ and stock exchanges-unfamiliar with shipping

\footnotetext{
${ }^{20}$ The usual procedure is for shipowners to comply with bank's pre-printed loan policy. We suggest the reverse: the bank to comply with company's plans, which have to take into account shipping cycle. e.g. in a slump, loan's installments should be lower.

${ }^{21}$ Banks give an umbrella when the sun is shining and take it back when it is raining...
} 
cycles-are reluctant to provide credit. To face this, shipping manager needs economic expertise. The adoption of "crisis reserves" from past profits, given the cyclicality of shipping markets, is e.g. wise. Strategic companies have to "manage" their loans so as to adapt loans to ${ }^{22}$ company's cycle and avoid defaults.

\section{$\checkmark$ To charter ships}

Sales = chartering: to let ship's space for hire, or for freight, (the failure here is "total"); chartering expertise may not be a property of all shipping managers; in that case, a large company relies heavily on a number of specialized in-house ship-brokers. As this function achieves the sales of the company, it should be placed in the $1^{\text {st }}$ and prime position in a company. If a company has a top manager expert in chartering, this may become a "competitive advantage", and the relevant particular policy for the company is to select the most profitable, in the end, charters among all other offers.

- To operate ships

Production = operations: i.e. to implement a "charter party" as agreed by company's chartering (a failure here damages company's reputation in the eyes of charterers); a non-failure brings-in a number of benefits. The policy needed here is to "minimize the off-hire ${ }^{23}$ time of ships"; and satisfy charterers.

The successful operation of ships is a 2 nd important task of a shipping company, occupying also most of company's time ${ }^{24}$. In operations a manager should manage not only costs, but also company's revenue-something neglected. This is a function connected with company's performance and it is here where company can be close to charterers.

\section{$\checkmark$ A shipping company closer to charterers}

Traditionally, it is true, that shipping industry did not pay attention to its customers (Lorange, 2009 [6] p. 105), due to the fact that almost all customers' demands entailed a cost. Moreover, this was due also to the fact that shipping provides "homogeneous" services, and as a result, it did not matter "who is who" in ownership.

Eventually, a sense of safety created-under the pressure of certain marine accidents, where management had clearly failed (Goulielmos and Goulielmos, 2005 [33]). Moreover, certain shipowners owned fleets of lower average age, more experienced/educated crews, better ship maintenance and reputation, fewer marine accidents, etc.

While any payment to owners does not depend on safety, and on all the above mentioned factors-when available cargoes are fewer than ships-safety of service counts and charterers prefer "safe ships of low age". This may be called "no ${ }^{22}$ A Greek shipping company bankrupted when a slump followed its ambitious newbuilding program (e.g. the "Colocotronis" case; see Couper, 1999 [32], p. 37). The traditional Greek shipowners-since 1830s-did not order ships unless they had the full amount cash, which usually was adequate for one ship at a time. Onassis was the first to smash this tradition by "using other's people money". "Rapid growth" in shipping is done by using other's people money, risking that proper demand will be there.

${ }^{23}$ When vessel moves round without paid cargo (in ballast), where her costs run and revenue stops.

${ }^{24}$ To fix a ship with a charter it may take say one or two days on average; to operate a ship it may take up to 30 days. 
price competition"-NPC, though none of NPC characteristics applies much to shipping: advertising, marketing, and service innovation.

In addition, "management" changed its focus from the supply side (technical perfection in production) to demand side (sales; customer's satisfaction etc.), following "total quality management"25 (TQM) (since 1991) (Priesmeyer, 1992 [34] p. 154) and the subsequent theories of marketing and the ISO, and ISM Code standard (since 1998). The above developments changed the attitude of shipowners towards charterers, and especially those called "majors" or seven sister $^{26}$ in Oil transport. Charterers ${ }^{27}$ after all are those that provide the revenue and the reason for which a shipping company is in business.

$\checkmark$ To maintain ships, to innovate

The policy required is related to changes that a manager (more so if he/she is a former engineer/naval architect) asks ((through his/her supervising superintendent engineer(s)) -in the case of a shipbuilding contract. This is connected with "innovative management". Also, the technical evaluation of $2^{\text {nd }}$ hand ships is also of utmost importance in the acquisition process. The technical side of ships is the most difficult for managers without a prior technical expertise-a case where a manager is obliged to rely heavily on his/her technical manager. Linear and nonlinear strategies will be now presented, and distinguish ones from the others for a possible benefit to shipping managers from both ${ }^{28}$.

\section{Linear Management Strategies}

"Linear Management-LM"-strategies are plans, of how: a company will carry-out its businesses; it will compete (its competitors) - successfully-and it will attract (and satisfy) its customers, by achieving company's goals $s^{29}$ (Robbins and

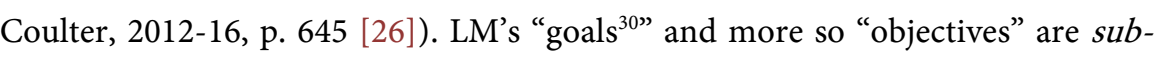
ordinate to company's "mission"31. They are shorter-term concepts purposed to challenge personnel in operations: i.e. products of linear thinking (Priesmeyer, 1992, [34] p. 195).

$\checkmark$ Company's mission

Mission is central. The past status of a company-we believe-needs to be known, before a manager plans to make it strategic or more strategic. The mis-

\footnotetext{
${ }^{25}$ One element of TQM is the "intense focus on customer" (Robbins and Coulter, (2012-16), p. 34 [26]).

${ }^{26}$ I.e. Chevron, Esso, Gulf, Mobil, Texaco, BP and Shell.

${ }^{27}$ Lorange (2009 [6] p. 105) reports-as an indication of how shipping companies can be closer to their customers-the appointment of the ex-CEO of "Carlsberg" to head "A.P. Moller-Maersk" (a containership giant owner). Our analysis, however, is centered most to "Bulk shipping", which is not so prone to BB marketing as containerships (Goulielmos-Plomaritou, 2009 [29]).

${ }^{28}$ For LM we have in mind mainly the work of Robbins and Coulter [26].

${ }^{29} \mathrm{Goals}$ (called also objectives) are desired outcomes, or targets, for a company, determined by management during company's planning process; see Molz (1987) [35], (mentioned by Robbins and Coulter (2012-16) [26]), explaining how leaders use goals.

${ }^{30} \mathrm{The}$ goals in the example of a hospital are: to "remodel the east wing within 18 months and reduce utility costs by $15 \%$ in 12 months".

${ }^{31}$ These are broadly termed purposes.
} 
sion (Figure 9), we believe, ties also company with its past-as it states the purpose of the company for which company was and is in business.

Mission, normally, determined long ago by company's founder. It was perhaps a novel idea at its time, which brought success to company, since conceived and implemented. It remains live as long as it serves an existing, enduring, and perhaps expanding need (e.g. in other countries like China). Mission, however, should be adaptive ${ }^{32}$ - in our opinion-as time goes-by by retaining possibly its core original meaning (e.g. McDonalds), as mission needs change (given new technologies as well company's greater size and other changing factors).

However, the way LM presents "mission" implies that we have to deal mainly with present (Robbins and Coulter, op. cit., p. 238 [26]). Mission looks like an effort for company's management to take seriously into account a number of 9 important factors (Figure 9) (Fred (2011) [36]), which we reckon LM manager should know-i.e. a kind of "aide de memoir". We can, however, make this dynamic, if we plan to "change" the 9 factors...or better study their changes from year to year. LM further talks about "visionary leadership" required only if company's leader is going to improve upon present situation (Robbins and Coulter, op. cit., pp. 502, 651 [26]) and Lucas (1998) [37]) for vision statement as mentioned by Robbins and Coulter [26], p. 634. LM places vision as a characteristic of a charismatic leader, among another 4 characteristics (Conger and Kanungo, 1998, [38]).

\section{$\checkmark$ Generic strategies-GS}

GS are due to Porter (1980 [39], chap. 4) and cover: (1) "cost leadership", (2) "differentiation" and (3) "focus". Focus is a rather recent addition to strategies. In shipping, "survival" (Goulielmos 2017 [17]), is a more common strategy, and

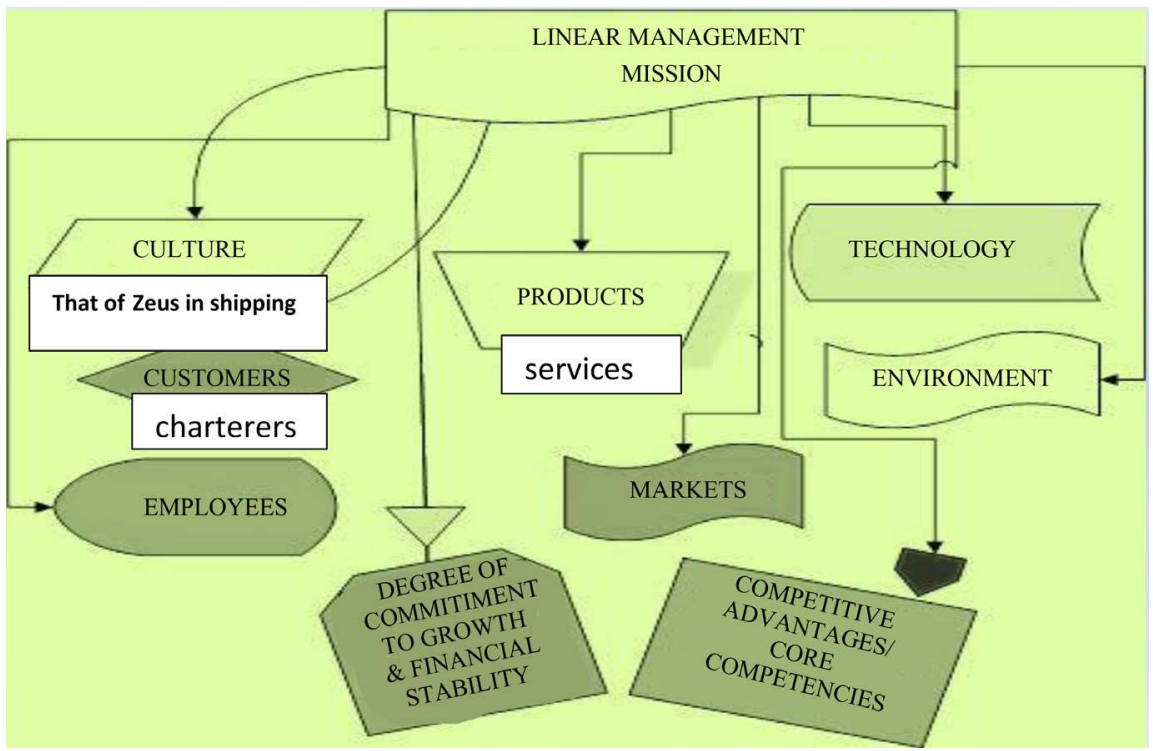

Figure 9. The "linear management" mission over 9 areas. Source. Robbins and Coulter (2012-16) [26], p. 238.

\footnotetext{
${ }^{32}$ Authors here are in disagreement.
} 
"cost minimization" is a way for this, especially in a slump, as the service price cannot be increased... as mentioned.

$\checkmark$ Differentiation strategy

In shipping, "service differentiation" is not possible (bulk sectors). One opportunity for shipping firms to differentiate their services was safety, but ISM Code legislated by IMO 20 years or so ago (1993; 1998; 2002), was compulsory. Nevertheless, shipping companies can boost their reputation by announcing company's records for (few or zero) marine accidents and for (low) average age of ships-owned, list of (major) charterers and an improved public image. But all these do not gain a higher price.

\section{Nonlinear Management Strategies-Nlms ${ }^{33}$}

Certain authors believe that the $3^{\text {rd }}$ global revolution is "nonlinear" management (Peters, 1994, [40] p. 9). Shipping companies are complex systems and the certainties of the "command and control" approach to management due to Newton (Goulielmos, 2015, [25]) no longer holds true. Complexity deals with the nature of emergence, innovation, learning and adaptation (Santa Fe Group, 1996 cited by Battram, 1998 [41] p. 12). Based on "Chaos and Complexity" companies in general, and shipping companies in particular, are nonlinear systems. So, we have accordingly to use nonlinear tools to "manage these companies". Nonlinear management (Priesmeyer, 1992 [34]; Battram, 1998 [41]) takes real corporate performance data and shows the underlying behavior that exists.

In nonlinear ${ }^{34}$ management, an "internal analysis" is also recommended, but based on changes in firm's conditions. Interesting is to see whether company's strengths and weaknesses showed an improvement. If the answer is positive, then these should be made strategic advantages. "Nonlinear management strategies" are also plans, for company's macro future, and for strategies, which determine company's mission ${ }^{35}$, and positioning ${ }^{36}$ (relatively to its competitors); strategies are then selected and implemented (throughout the company).

The main NLMS targets are: to "compete", "survive" and "grow", by realizing in depth, company's business environment [34]. To focus only on company's future, is rational, given that present cannot change. Moreover, "visioning" should be integrated into company's strategic planning to quantify company's mission. In NLMS, we rely heavily on "vision" ${ }^{37}$. The vision statement has an interesting definition: it "can help management to define company's future, which management... wants" [34]. With this definition the role of company's management is greatly upgraded...

\footnotetext{
${ }^{33}$ For NLMS we have in mind mainly Priesmeyer [34].

${ }^{34}$ The knowledge of the trajectory of changes in company's business activity before attempting to implement a change to it is required.

${ }^{35}$ For Priesmeyer [34], and for a "privately funded major city hospital in USA", mission is: "to provide quality medical care to district's population" (p. 196).

${ }^{36} \mathrm{This}$ is a strategy so that a brand to occupy a distinct position in the mind of customers.

${ }^{37}$ For the hospital example, vision is: "to attain a bed capacity of 300 (beds) and a budget surplus of $\$ 100,000$ within a year". Vision is, therefore, specific and talks about quantities.
} 
NLMS deal with company's changes occurred in recent past (last 4 years, but not exclusively) using trajectories that-come from the past-and have to be followed in future, using a nonlinear tool: the full "Cartesian" diagram. This is a mathematical space, which accommodates yesterday, today and tomorrow.... and where company is planning to achieve a vision.

$\checkmark$ The case-study of “Toro Corporation" (USA).

Toro $^{38}$ Corporation's actual changes in sales and in profits over 4 quarters (1979-1980) are presented, and connected with their trajectories (Figure 10). We have also placed company's vision in 1980 ( $2^{\text {nd }}$ quarter $)$. The vision is to "place" company to the "proper" ${ }^{39 \text { " }}$ quadrant, $\mathrm{Q}_{1}$; this is not quite difficult, given company's position in $1980-1^{\text {st }}$ quarter in quadrant 2 , which is rather close to the "visioned" one. As shown, company's vision entails a change of profits coming from a change in sales ${ }^{40}$.

$\checkmark$ The case-study of “Thiokol Corporation” (est. in 1929).

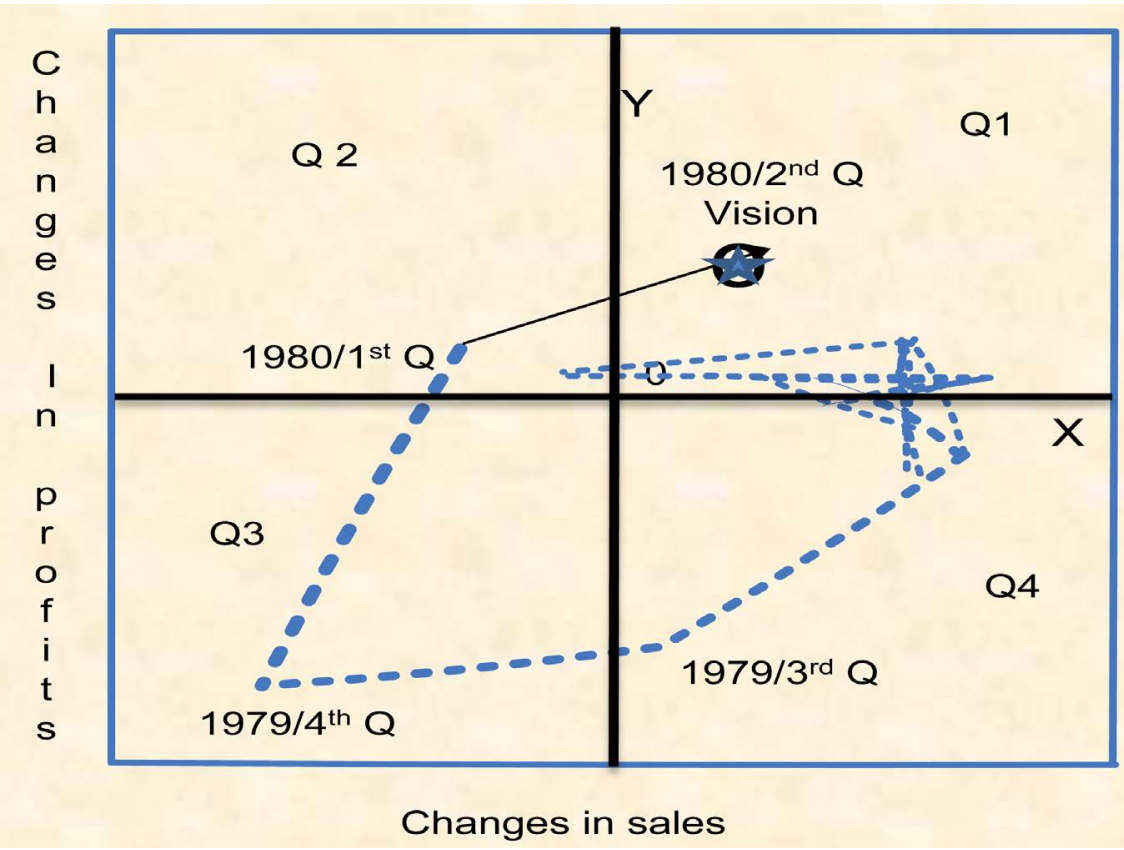

Figure 10. Managing a Company by visioning ("Toro ${ }^{41}$ Corp.") Source. Modified from Priesmeyer, 1992, p. 178 [34]. The above is a full Cartesian diagram with 4 quadrants. $L M$ uses only quadrant $1(Q 1)$.

${ }^{38}$ The Toro (=Bull) corporation founded in 1914 (in Minneapolis); it employs 6000+ persons with sales of $\$ 2 \mathrm{~b}$ in 2013 from $\$ 1.8 \mathrm{~b}$ in $2005 \ldots$ and $\sim 178 \mathrm{~m}$ in 1980 ; traded since 1978 in NYSE (Priesmeyer (1992 [34]), pp. 54-56, 178-180).

39"Proper" is in the sense that both variables-sales and profits-increase.

${ }^{40}$ The more snow there is the more probable is for the company to sell more. Company's development over new products and markets, thereafter, was indeed remarkable: www.thetorocompany.com/companyinfo/history-brochure.pdf downloaded in Oct. 2017.

${ }^{41}$ It originally constructed "lawn equipment"; then passed to "snow throwers" and "chain saws", applying a "growth strategy". It faced 2 snowless winters...in 1979-80. It had high name recognition, established reputation for quality and good dealers' network. This strategy was also countercyclical as trading was done in summer too. The company this way utilized better its assets and stabilized its cash flow addressed to same customers. 
Chaos in management is distinguished in various levels: low, high etc. [34]. A company's management surely prefers to do business in a low-level chaos, where there is stability; the higher-order chaos moreover entails periodic oscillations. Figure 11 shows a random-appearing behavior, a measureless complexity, and a structured disorder... or in other words a high-order chaos.

"Thiokol Corporation ${ }^{42 "}$ is a company listed in NYSE. In the horizontal axis we measured changes in company's sales and in vertical axis changes in earnings per share, for the last 48 months of company's businesses ${ }^{43}$; it shows also that the company found itself, at the end of the period, in quadrant Q3, where both changes in sales and changes in earnings...fell.

The pattern of this company shows 8-period trajectories-which means highorder chaos... The company indeed faced a turbulent external environment; and its management's decisions made apparently without knowledge of the structural patterns of change bound the company. The company had to reduce company's chaos from an 8-period cycle to a 4-one to begin with. This would be done if company's trajectory visited one combination of visits in 1,4,2,3 quadrants, and in that order $^{44}$ or in $2,4,3,1$. Here the total combinations are not 2, but 16 $\left(4^{2}\right)$.

\section{$\checkmark$ "Eletson Corporation"}

Table 2 gives company's sales from 1988 to 2000-years for which this confidential data are only available-and company's revenue in million dollars

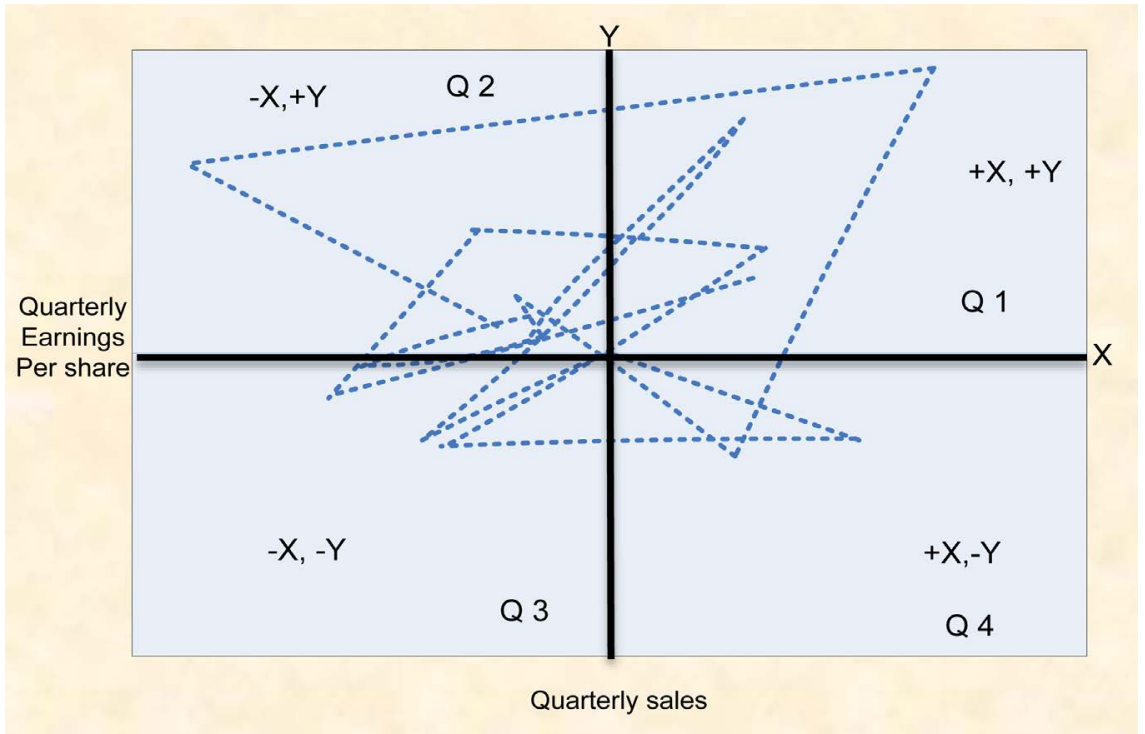

Figure 11. "Thiokol Corporation" Source. Constructed by author; adapted from Priesmeyer (1992) [34] p. 23).

\footnotetext{
42“Thiokol corporation" is a US company producing rocket engines, employing 15,000 persons (http://en.wikipedia.org/wiki/thiokol d. 08/06/2015). In 1986 the company had the bad luck for space shuttle "Challenger" to explode with people dead. Its annual sales were $\$ 840 \mathrm{~m}$.

${ }^{43} \mathrm{We}$ plot the 4 most recent quadrant visits.

${ }^{44}$ There are 14 additional situations where a company can be found with a 4 period limit cycle: $1,2,4,3 ; 1342 ; 1324 ; 4123 ; 4321 ; 4231 ; 4213 ; 3241 ; 3421 ; 3142 ; 3124 ; 2134 ; 2314 ; 2413$; where numbers indicate quadrants visited by company's trajectory.
} 
Table 2. Company's sales (cargo carried in million metric tons) from 1988 to 2000 and company's revenue in thousand dollars from 1987 to 2000.

\begin{tabular}{cccc}
\hline \multicolumn{2}{c}{ Revenue (ooo's US\$) } & \multicolumn{2}{c}{ Cargo carried } \\
\hline 1987 & 54,641 & in MT & R per ton \\
\hline 1988 & 56,641 & --- & -- \\
1989 & 65,260 & $5,481,741$ & $\$ 10.33$ \\
1990 & 61,302 & $6,559,861$ & $\$ 9.95$ \\
1991 & 76,067 & $5,394,504$ & $\$ 11.36$ \\
1992 & 85,606 & $6,637,136$ & $\$ 11.46$ \\
1993 & 115,044 & $9,650,769$ & $\$ 8.87$ \\
1994 & 118,762 & $10,227,326$ & $\$ 11.25$ \\
1995 & 150,301 & $10,704,040$ & $\$ 11.09$ \\
1996 & 140,732 & $12,668,400$ & $\$ 11.86$ \\
1997 & 149,739 & $11,221,866$ & $\$ 12.54$ \\
1998 & 127,616 & $11,075,501$ & $\$ 13.52\left(^{*}\right)$ \\
1999 & 120,906 & $11,565,067$ & $\$ 11.03$ \\
2000 & 202,800 & $11,937,682$ & $\$ 10.13$ \\
\hline
\end{tabular}

Source. Data from Company’s 2001 booklet; $\left({ }^{*}\right)$ (higher).

(1987-2000). Additionally, the revenue \$ per ton is also calculated. Worth noting is that "price" is cyclical (Figure 13).

Figure 12 shows company's "sales" having a positive rising relationship with "revenue collected" (trend line). This makes shipowners happy. But the "blue circle" indicates where the trouble was, as only in 1995 and in 2000 company achieved the higher yearly revenue of the period, i.e. $\sim \$ 150 \mathrm{~m}$ and $\sim \$ 201 \mathrm{~m}$. In 1996, the company had a fall in revenue of $\$ 10 \mathrm{~m}$, in 1997 a rise of $\$ 9 \mathrm{~m}$, in 1998 a fall of $\$ 22 \mathrm{~m}$ and in 1999 a fall of $\sim \$ 7 \mathrm{~m}$; or a $\$ 30 \mathrm{~m}$ fall altogether.

In 2000 company had an exceptional rise in revenue of $\$ 82 \mathrm{~m}$; we reckon that $1 / 2$ was due to company's management and $1 / 2$ due to market! In 2000, company added $3 \mathrm{~m}$ metric tons carrying capacity $(+37.5 \%)$, which brought-in almost half $(49 \%)$ of the revenue, i.e. $\$ 40 \mathrm{~m}$ on average ( $3 \mathrm{~m} * \$ 13.4$; from Table 2$)$. The remaining $\$ 42 \mathrm{~m}$ was due to improved freight market.

Has the company deteriorated its market by adding ${ }^{45}$ a large amount of tonnage to market's supply? We found that in 2005-500 m tons carried by sea of "oil products" globally [42]. So, the $3 \mathrm{~m}$ metric tons covered-by estimation- 1\% of total demand (300 m metric tons) in 2000 , which is not much. But we have to

45"Sanko" in 1983 and in 1973 increased market's supply with large amounts. Couper ((1999), p. 37, [32]) blamed Sanko company's management for ignorance of the bulk market and the easiness company could obtain finance. Company's project involved $~ 1 / 6$ of Japan's fleet or $3 \%$ of global fleet! The company ordered... 125 handy-sized bulk carriers (say of 30,000 - 35,000 dwt each), meaning $3.75 \mathrm{~m}$ dwt or $4.37 \mathrm{~m}$... 


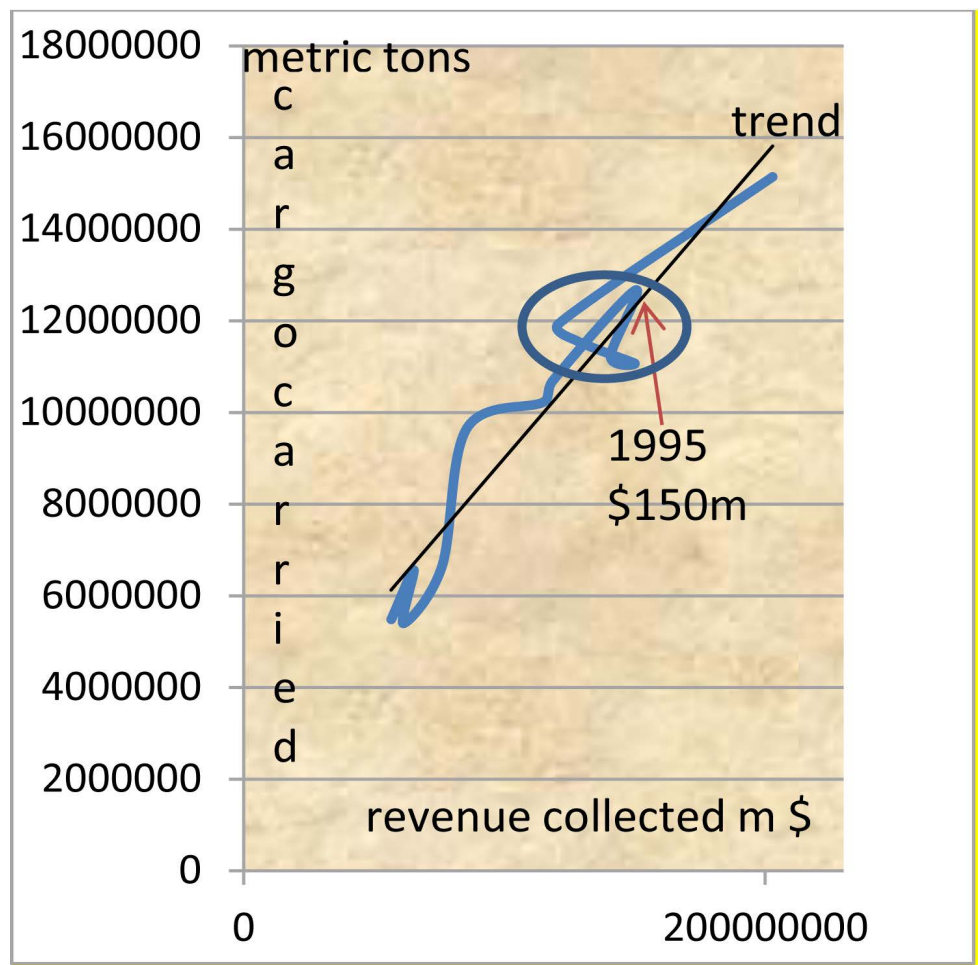

Figure 12. Eletson Corp. 1988-2000, cargo Source. Table 2.

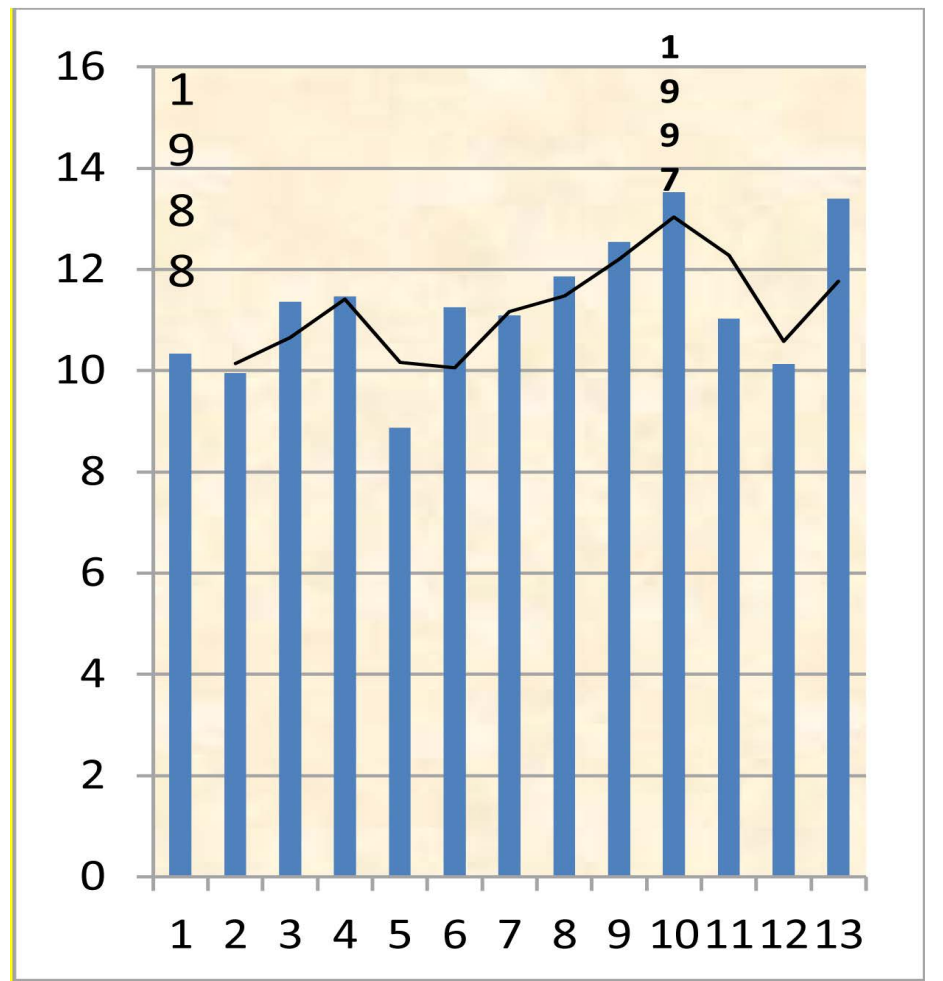

Figure 13. Average revenue, 1988-00 carried versus revenue obtained.

see what all owners have ordered, scrapped and how many ships lost. Figure 13 shows also "average revenue"-or price-which, as expected, is cyclical. Simi- 
larly, Sanko ${ }^{46}$ did not cause the 1981-1987 shipping depression, but it made it deeper. So, we can blame both "Sanko" and "Eletson" for failing to estimate demand at the time of the delivery of their ordered ships... Now, Figure 14 gives us the full Cartesian diagram for Eletson Company.

As shown, changes in company's sales are marked horizontally, as this is the independent variable $\mathrm{X}$, and changes in revenue marked on vertical axis, as the dependent variable $Y$, for last 4 years, 1997-2000. Figure 14 shows the trajectories starting from year 1997, from the point determined by revenue and sales amounts, and go up to 2000 (heavy black lines). The visits of the trajectories were in quadrants: 2, 4, 4, 1 (1997-2000). The company had two visits in quadrant 4, where revenue is reduced; one visit was in quadrant 2 , where $\mathrm{Y}$ increased, which is not bad, but this cannot be attributed to company's strategy, but to market, which paid the higher price for this period...\$13.52 per metric ton.

Figure 14 indicates the high-order chaos (period 8). In this particular casestudy chaos is created by the fact that while sales increased (1998; 1999), revenue fell. This means that increased sales did not obtain higher prices. This is so as the "price" in 1998 was \$11.03 and for 1999 \$10.13, vis-à-vis 1997 (\$13.52) and 2000 $(\$ 13.40)^{47}$.

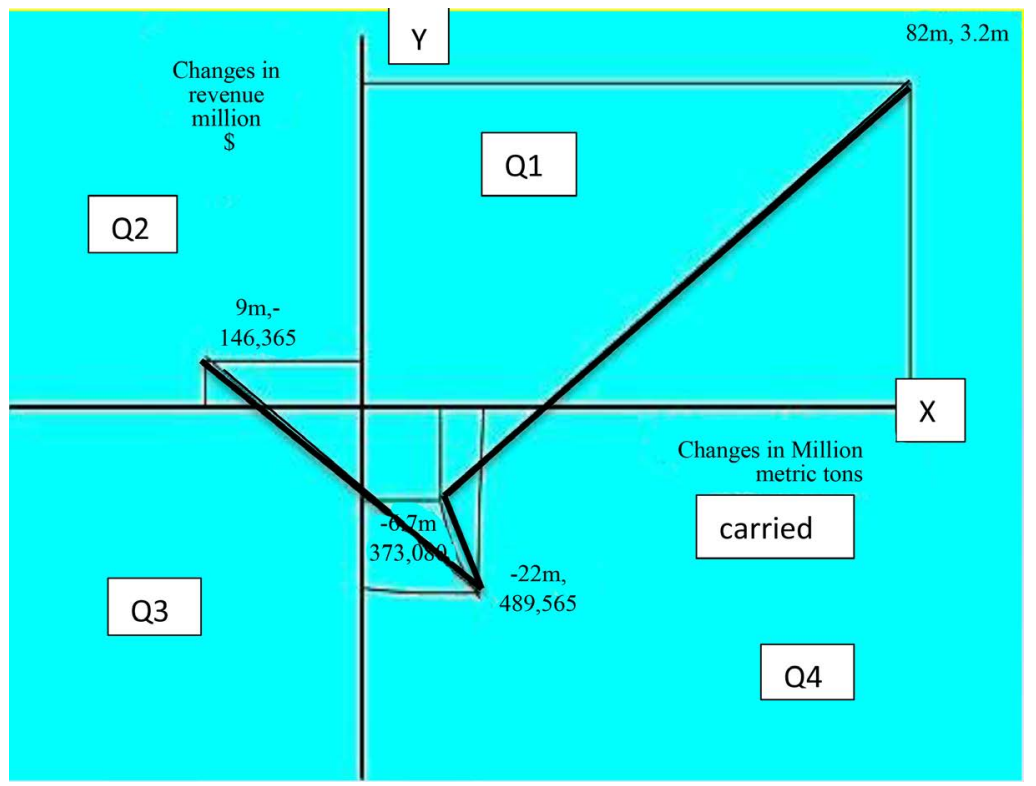

Figure 14. "Eletson Corporation" trajectories, 1997-2000. Source: Table 2.

\footnotetext{
${ }^{46}$ Sanko had a double wrong thinking. First, it was dedicated in tanker business-putting all company's eggs in one basket-ordering 50 tankers; tankers in 1973-end entered into a severe depression. Company's management thought (1983) that by doubling company's size with enough bulk carriers -which at the moment were not in depression-would balance company's losses. Thus it ordered $\sim 4 \mathrm{~m}$ dwt... of bulk carriers. The other mistake was that company believed in a 4 -year cycle, with 2 years up and 2 years down; so it ordered in 1983, so that to have the ships in 1985, believing that in 1981-1982 the cycle went down and in 1983-1985 it will go up! The market, however, recovered 18 months later, in $19871^{\text {st }}$ half. In fact other shipowners "informed" about this, and as shipping companies copy others, they rushed to order ships making influence on supply greater.

${ }^{47}$ This means that $\$ 13.52$ minus $\$ 11.03=2.49 * 11,565,067$ metric tons gives a lesser amount of $\sim 29$ $\mathrm{m}$ and for $1999,11,937,682 * \$ 3.39$ gives less $\$ 40.5 \mathrm{~m}$.
} 
Figure 14 is a well-known diagram due to Descartes (1596-1650). Linear management uses only one quadrant: the right hand upper one-as shown in Figure 12. This is a "pink" picture of the market. Sales increase and profits increase. Nonlinear management focuses on all 4 quadrants using for this purpose the changes in the variables involved (in quadrant 1 both $\mathrm{X}$ and $\mathrm{Y}$ increase; in 2 $\mathrm{X}$ falls and $\mathrm{Y}$ increases; in 3 both variables fall and in $4^{\text {th }} \mathrm{X}$ increases and $\mathrm{Y}$ falls) (Priesmeyer, 1992, p. 28 and thereafter, [34]). The visits of the combined X,Y trajectories each time (say year) will lead us to detect the level of chaos following the table 2.2 of page 40 in Priesmeyer (1992, [34]).

The low period 1 chaos is given by 1111 etc. visits. The medium chaos is given by 1112 etc. Higher levels are given by 1423 etc. for period 4 and for period 8 are 155 combinations shown by default. The high order chaos i.e. 8 is common in business (Priesmeyer, [34], p. 35) and this is the result of turbulent external environments and management decisions made without knowledge of the structural patterns of changes that bind the company.

$\checkmark$ Span of management and span of control

Management in shipping is done by distance-as mentioned-and a shipping manager always wonders whether his/her "span of control-SC" is proper vis-à-vis company's "span of management" and growth strategy. The dilemma for a shipping manager is: "how many ships should I control"? The "Span of control" is the number of captains a manager can efficiently and effectively manage. This obviously differs from manager to manager and this is the reason for different performances among shipping companies.

The concept of "span of management-SM" is simply the number of (existing) ships to a manager. A small SM means that ships/captains are more closely supervised, and thus they have less decision-making authority-perhaps to their dissatisfaction ${ }^{48}$. So a shipping manager may consider to delegate more decisionmaking to his/her captains. An improved SM-qualitatively-obviously can be done through M.HRM- “marine human resources management” for selecting the best available captains, doing their job with minimum supervision.

When we transfer these concepts to company's office, the larger SM makes a shipping company flatter, and permits also a faster decision-making-important for shipping companies; the greater simplicity in shipping companies achieved also by computers.

Interesting is to present the two concepts together (Figure 15).

Let a shipping manager finds his/her company to have a relationship between "span of management" and "span of control" denoted by B. At B, the number of captains/ships increased, perhaps due to growth strategy by building or buying ships; but the ability of the manager to control them declined. This leads to inefficiency. Moving to D, the manager improved his/her span of control, but this might be done because the number of captains/ships reduced, as perhaps a number of ships sold. At $\mathrm{C}$ both controls decline. As a result $\mathrm{A}$, where a shipping ${ }^{48}$ This happened in Norwegian shipping, where officers were highly educated and experienced so that to be disappointed by the limited freedom in decision-making, which the shore office allowed! 


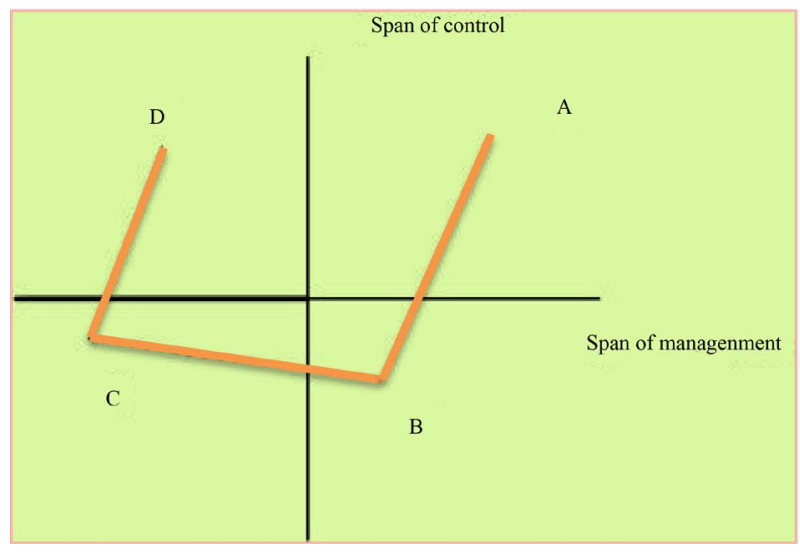

Figure 15. Span of control and span of management. Source. inspired by Priesmeyer, 1992, [34], p. 157.

company's span of management and span of control increase proportionally, is the desirable one (at a $45^{\circ}$ degrees trajectory).

As Lorange (2009 [6], p. xv) argued: I sold my shipping company in 2007 (Jan.)...the major rationale was that "I began to feel increasingly uncomfortable attempting to combine various aspects of shipping under one organizational roof... owning, chartering and innovating...an increasingly complex situation..."

We have met Greek shipowners that the right span of control over their captains and engineers allowed them to be small (say 5 - 10 ships). Other, manage ships of a great number of ships (= 39 in May 2009) and tonnage... (e.g. "The namaris ship management Inc." www.thenamaris.com).

- Paper's main contributions

The paper has tried to provide a concise presentation of two qualitatively different approaches to managing companies, as well as managing shipping companies. The reader who knows linear management may benefit from the nonlinear management analysis provided, who we presumed he/she ignores. Our opinion of course is to replace linear management by nonlinear one, but this would be neither wise nor acceptable. Every manager should ask we believe: "is business world nonlinear?"

Moreover, we showed the crucial issues that a shipping company faces, in order of importance, dissolving also some wrong assumptions. We considered that it is important for managers to be able to discover the level of chaos the company they manage faces and thus to rectify its situation. We showed that shipping company "Eletson" embarked wrongly on an extensive shipbuilding program without estimating future freight market-the error was revealed clearly only by nonlinear analysis.

\section{Conclusions}

Linear management strategies' list is a shopping one, (we presented 22), which we believe do not help much shipping managers. Obviously research is unset- 
tled. Moreover, linear theory is not satisfied even with leadership, but it needs now it to be effective. Moreover, a strategy is not a way to make money.

The 1970 "strategic planning model" of general Electric, surely had to change. The order of its steps had to change too: SWOT analysis should be prior to company's mission. In addition, no company was ever unable to achieve its mission, as in most cases mission is broadly stated (= achievable). Also, internal analysis should be based on changes in organizational conditions. In addition, and more important, company's vision is absent, and is dependable on leadership, and on a new term of leadership called "effective", which appeared in 1999.

Nonlinear management is dynamic as it uses changes in variables overtime; it can be used also for "management by visioning". Moreover, it may indicate the order of chaos. It also indicates where and when management has failed and how far the recent situation is away from the desirable outcome in quadrant 1. Also, it shows which variables have to be improved.

Linear Management has paid attention exclusively on "span of control", which is more difficult to measure, including the two "confusing" concepts of efficiency and effectiveness. Nonlinear management added "span of management".

Ten maritime countries and 10 shipping companies adopted the strategy of "maximizing their fleets" (a "growth strategy within the industry" = horizontal) by spending serious amounts to obtain new ships.

The best strategy for shipping is to have a shipping manager-having dexterity in $1^{\text {st }}$-best timing-who can buy 2 ships... at the price of one... with same money-at different times. This indirectly means to double company's size using the same capital! Research has found also that the $1^{\text {st }}$-best timing sale of a ship provides the company with 3 yearly profits from her operations... Here is "all the wisdom about shipping strategies" in one simple strategy: "best timing".

One condition of "perfect competition" does not hold, as an individual (large) shipping company can influence Supply, as we showed. Thus, competition is valid only in demand's side.

A final conclusion, which can be drawn, and perhaps is repeated, is that a successful shipping manager has to apply $1^{\text {st }}$-best timing or even $2^{\text {nd }}$-best one, at all times and minimizing the costs of the company permanently. The growth strategy-followed by the great majority of shipping companies and the 10 top maritime countries-is recommended, but on the condition that demand is there, through forecasting and by using other people's money and paying special attention to company's liquidity. Greeks have adopted a traditional and successful shipping policy so far: buy/order at rock bottom prices, sell smaller and older ships by maintaining or increasing present fleet in the end.

\section{Further Research}

A desirable further research is the one that will combine profits with one appropriate strategy. We repeat the questions posed by Magretta [43]: "How do we make money in this business?" What is the underlying economic logic that explains how we can deliver value to customers at an appropriate cost?". 
Moreover, the more realistic theory of management, i.e. the nonlinear one, has to expand further-since 1992 - to reach up the level/volume of linear management. Further research has an extensive horizon to establish management dynamic tools beyond the few we have showed.

In addition, a better forecasting is essential for shipping that as we saw follows the traditional safe way of ordering/buying cheap larger and younger capital goods in a strategic timing together with a strict management of total cost pursuing at the same time economies of scale. This ends to a growth strategy and the creation of competitive advantages: larger size, lower cost, more efficient capital goods etc. And all this without the help of a management theory-linear or nonlinear-but making actions that follow their father's policy, which has been tested over centuries and proved successful. Further research is called to help shipowners and not live them indifferent.

Surely, we have to start with listed companies that provide transparency and perhaps allow research on their strategies. Secrecy in shipping industry no doubt prevents research and thus management theorists cannot create models and strategies for them.

\section{References}

[1] Goulielmos, A.M. (2004) Management of Shipping Companies. 4th Edition, A. Stamoulis Publications, Athens. (In Greek)

[2] Goulielmos, A.M. (2002) Complexity Theory Applied to Management of Shipping companies. Maritime Policy \& Management, 29, 375-391. https://doi.org/10.1080/03088830210144305

[3] Goulielmos, A.M. (2017). Strategies in "Shipping Business Management". Modern Economics, 8, 1211-1229. https://doi.org/10.4236/me.2017.810083

[4] Theotokas, J. and Harlaftis, G. (2007) Greek Shipowners and Shipping Enterprises: Organization, Management and Strategy. In: Alexandria, Ed., Athens (In Greek); Leadership in World Shipping (2009), Palgrave Publ.s.

[5] Lorange, P. and Norman, V.D. (1973) Shipping Management. Institute for Shipping Research, Bergen.

[6] Norman, V.D. (1982) Market Strategies in Bulk Shipping, a Working Paper, Norwegian School of Economics and Business Administration, Bergen.

[7] Lorange, P. (2005) Shipping Company Strategies: Global Management under Turbulent Conditions. Elsevier. https://doi.org/10.1108/9780080458069

[8] Lorange, P. (2007) Leaders: Questions and Answers with Gerry Wang. 30, 58-61.

[9] Lorange, P. (2008) Thought Leadership Meets Business. Cambridge University Press. https://doi.org/10.1017/CBO9780511488474

[10] Lorange, P. (2009) Shipping Strategy: Innovating for Success. Cambridge University Press.

[11] Lorange, P. (2010) Leading in Turbulent Times: Lessons Learnt and Implications for Future. Emerald.

[12] Lorange, P. and Fjeldstad, O.D. (2010) Redesigning Organizations for the $21^{\text {st }}$ Century: Lessons from the Global Shipping Industry. Organizational Dynamics, 39, 184-193. https://doi.org/10.1016/j.orgdyn.2010.01.007 
[13] Lorange, P. and Fjeldstad, O.D. (2012) New Business Models and Strategies in Shipping. Wiley-Blackwell Editions.

[14] Buckley, J.J. (2008) The Business of Shipping. 8th Edition, Cornell Maritime Press, a Continuation of the Book of Kendall I.C.

[15] Huber, M.E. (2010) Tanker Operations: A Handbook for the Person in Charge. 5th Edition, Cornell Maritime Press, a Continuation of the Book of Marton, G.S.

[16] Packard, W.V. (1981) Sale and Purchase Tramp Ship Series, "Fairplay" Publications, Great Britain.

[17] Downard, J.M. (1981) Running Costs, Ship Management Series, "Fairplay" Publications, Norfolk.

[18] Downard, J.M. (1984) Managing Ships, "Fairplay” Publ.s.

[19] Phelan, S.E. (1995) From Chaos to Complexity in Strategic Planning. http://www.aom.pace.edu/bps/papers/chaos.html

[20] Levy, D. (1954) Chaos Theory and Strategy: Theory, Application and Management Implications. Strategic Management Journal, 15, 167-178. https://doi.org/10.1002/smj.4250151011

[21] Stacey, R.D. (1991) The Chaos Frontier. Butterworth-Heinemann, Oxford.

[22] Stacey, R.D. (1993) Strategic Management and Organizational Dynamics, Pitman.

[23] Vinten, G. (1992) Thriving on Chaos: The Route to Management Survival. Management Decision, 30, 22-28. https://doi.org/10.1108/00251749210022168

[24] Kellert, S.H. (1993) In the Wake of Chaos = Unpredictable Order in Dynamical Systems. Chicago University.

[25] Goulielmos, A.M. (2015) How Complexity and Chaos Theory Reformed Management. Archives of Business Research, 3.

[26] Robbins, S.P. and Coulter, M. (2012-2016) Management 13E, Pearson.

[27] Goulielmos, A.M. (2017) The Great Achievement of Greek-Owned Shipping (19462017) and Keynes' Animal Spirits. Modern Economy, 8, 1186-1210. https://doi.org/10.4236/me.2017.810082

[28] Pearce, D.W. (General Editor) (1992) Macmillan Dictionary of Modern Economics. 4th Edition, GB.

[29] Goulielmos, A.M. and Plomaritou, E. (2009) A Review of Marketing for Tramp Shipping. Shipping Transport \& Logistics, 1, 119-155. https://doi.org/10.1504/IJSTL.2009.024492

[30] Besanko, D., Dranove, D., Shanley, M. and Schaefer, S. (2010-2013) Economics of Strategy. 6th Edition, J. Wiley \& Sons Singapore Pte. Ltd.

[31] Goulielmos, A.M. (2017) Myths about Forecasting, Business Cycles and Time Series: With an Application to Shipping, Advances in Modern Economy.

[32] Couper, A.D. (1999) Voyages of Abuse: Seafarers, Human Rights and International shipping. Pluto Press, London.

[33] Goulielmos, A.M. and Goulielmos, M.A. (2005) The Accident of M/V "Herald of Free Enterprise": A Failure of the Ship or of the Management? Disaster Prevention \& Management, 14, 479-492. https://doi.org/10.1108/09653560510618320

[34] Priesmeyer, H.R. (1992) Organizations and Chaos: Defining the Methods of Nonlinear Management. Quorum Books, CT, USA.

[35] Molz, R. (1987) How Leaders Use Goals. Long Range Planning, 91. https://doi.org/10.1016/0024-6301(87)90096-3 
[36] Fred, R.D. (2011) Strategic Management. 13th Edition, Pearson Publ.

[37] Lucas, J.R. (1998) Anatomy of a Vision Statement, Management Review, 22.

[38] Conger, J.A. and Kanungo, R.N. (1998) Charismatic Leadership in Organizations, 1,000 Oaks. Sage, 633.

[39] Porter, M. (1980) Competitive Strategy, Free Press, NY.

[40] Peters, E.E. (1994) Fractal Market Analysis: Applying Chaos Theory to Investment \& Economics. A Wiley Finance Edition.

[41] Santa Fe-Team (1996) Quoted by Battram.

[42] Bartram, A. (1998) Navigating Complexity, Industrial Society, London.

[43] Magretta, J. (2002) Why Business Models Matter, Harvard Business Review, May, 13. https://hbr.org/2002/05/why-business-models-matter 